\title{
Comparative analysis of the competitiveness of Beninese and Brazilian cotton exports in international trade from 2006 to 2018
}

\author{
Análise comparativa da competitividade das exportações beninenses \\ e brasileiras do algodão no comércio internacional de 2006 a 2018 \\ Codjo Olivier Sossa ${ }^{1,2}$ (D) \\ 1Programa de Pós-graduação em Economia (PIMES), Universidade Federal de Pernambuco (UFPE), Recife (PE), Brasil. \\ E-mail: oliviersossa@gmail.com \\ ²Programa de Pós-graduação em Estatística, Universidade Federal de Pernambuco (UFPE), Recife (PE), Brasil.
}

\begin{abstract}
How to cite: Sossa, C. O. (2022). Comparative analysis of the competitiveness of Beninese and Brazilian cotton exports in international trade from 2006 to 2018. Revista de Economia e Sociologia Rural, 60(4), e235719. https://doi.
\end{abstract} org/10.1590/1806-9479.2021.235719

\begin{abstract}
This study aims to analyze the competitiveness and orientation of Brazilian and Beninese cotton exports in international trade from 2006 to 2018. The cotton category in this article refers to "neither carded nor combed" (HS: 5201). To measure competitiveness, we chose to calculate the Revealed Comparative Advantage Index (RCAI) and Symmetric Revealed Comparative Advantage Index (SRCAl), proposed by Balassa (1965) and Laursen (1998) respectively. The Regional Orientation Index (ROI), proposed by Yeats (1997), of cotton for Asia and EU-28 is used. The data were collected from the International Trade Center (ITC) /Trade Map and the United States Department of Agriculture (USDA). The results found indicate that the Brazilian's and Beninese's cotton has been increasing values and above the unit showing its competitiveness in the international market. In addition, Benin was more competitive than Brazil because it has, on average, a higher SRCAI than Brazil (0.99 and 0.7 respectively). Concerning the ROI, it was found that Brazilian and Beninese cotton exports are strongly directed towards Asia, the main consumer market for Beninese and Brazilian cotton. As for the EU-28, both Benin and Brazil do not direct their cotton sales to this economic block.
\end{abstract}

Keywords: cotton, revealed comparative advantages, regional orientation, Benin, Brazil.

Resumo: Este estudo tem como objetivo analisar a competitividade e orientação das exportações brasileiras e beninenses de algodão no comércio internacional de 2006 a 2018. A categoria do algodão neste artigo refere-se ao "não cardado e nem penteado" (SH: 5201). Para mensurar a competitividade, optou-se por calcular o Índice de Vantagens Comparativas Reveladas (IVCR) e Simétrica (IVCRS), proposto por Balassa (1965) e Laursen (1998), respectivamente. Utiliza-se o Índice de Orientação Regional (IOR), elaborado por Yeats (1997), do algodão para a Ásia e UE-28. Os dados foram coletados no International Trade Center (ITC)/Trade Map e do United States Department of Agriculture (USDA). Os resultados encontrados apontam que o algodão brasileiro e beninense vem apresentando valores crescentes e acima da unidade, mostrando suas competitividades no mercado internacional. Além disso, o Benin foi mais competitivo que o Brasil por ter, em média, um IVCRS superior que o Brasil (0,99 e 0,7, respectivamente). No que tange ao IOR, constatou-se que as exportações de algodão brasileiras e beninenses estão fortemente direcionadas para a Ásia, principal mercado consumidor do algodão do Benin e do Brasil. Já nos UE-28, tanto Benin quanto Brasil não orienta suas vendas de algodão para esse bloco econômico.

Palavras-chave: algodão, vantagens comparativas reveladas, orientação regional, Benin, Brasil.

\section{INTRODUCTION}

The world export of agricultural and livestock products increased by $97.03 \%$ between 2006 and 2018 , from US\$ 945 billion to US\$1.86 trillion respectively, and at the same time, its share in world exports has increased by $2 \%$ from $8 \%$ in 2006 to $10 \%$ in 2018 according to the World Trade Organization (2019) [WTO]. From the 2000s, the growth of the world economy was quite 
significant due to the influence of increased demand from emerging countries and the boom of commodities both mineral and agricultural (Vieira Filho \& Fishlow, 2017).

When analyzing the particularity of the cotton sector, compared to the year 2006, the world cotton export in 2018 reached a $46.10 \%$ growth, going from $\$ 10,89$ billion in 2006 to $\$ 15.91$ billion in 2018 according to International Trade Center (2020) [ITC]. As informed by the Associação Brasileira dos Produtores de Algodão (2020) [ABRAPA] database regarding the global export dynamics, "this industry involves more than 350 million people in its production, from farms to logistics, ginning, processing and packaging".

In this context, Benin, a West African Country, in the same period of 2006-2018, had a 301.61\% increase in agribusiness exports from $\$ 560$ million in 2006 to $\$ 2.249$ billion in 2018 (World Trade Organization, 2019). Benin is the world's sixth-largest exporter of cotton and the first in Africa in 2018 followed by Mali, Burkina Faso, and Ivory Coast (International Trade Center, 2020).

In 2018, Benin exported 259,577 tons of cotton compared to 76,020 tons in 2006 , or an increase of $241.56 \%$ comparing 2006 to 2018. The main exporters of this type of cotton are the United States of America (USA), Brazil, Australia, Benin, and Greece and account for approximately $80 \%$ of total combined exports according to the United States Department of Agriculture (2019) [USDA].

The buyers of this cotton produced in Benin are mainly Asian countries (Bangladesh, Malaysia, Vietnam, and China) (International Trade Center, 2020). The cultivation of cotton in the country was possible due to several factors: the availability of the area destined for its production; the attractiveness of the domestic market price; liberalization to the private sector; the progressive introduction of mechanization in production; the involvement of cooperatives in the organization and marketing of the product. According to the Institut National de la Statistique et de l'Analyse Economique, (2018) [INSAE], the increase in cotton production and its commercialization have contributed to the reduction of monetary poverty of the population in the country.

The government of Benin faces major challenges in international trade, among them, the tariff and non-tariff barriers that some major importers of Benin's products impose as a way to protect their economies. According to International Trade Center's (2015) research on tariff and non-tariff measures carried out in Benin in 2015, the results point out that on export, external measures are four times higher than the measures applied by Benin. Technical requirements (quality, packaging) and conformity assessment (analysis, certification, etc.) account for almost two-thirds of the measures implemented by partner countries. This trend is linked to the sector surveyed for export, represented mainly by agricultural and local agro-industry products.

In the Brazilian context in the analyzed period, sales have increased by almost $136 \%$ in agribusiness exports going from $\$ 35.9$ billion in 2006 to $\$ 93$ billion in 2018 (World Trade Organization, 2019). Its share in total Brazilian exports in 2006 was $28.75 \%$ and in 2018 it was $39 \%$. Also, according to International Trade Center (2020), Brazil's cotton exports reached $\$ 1.59$ billion in 2018 or $0.66 \%$ of Brazil's exports and almost $11 \%$ of world cotton exports in the same year 2018. In 2006, Brazilian cotton exports were $\$ 0.338$ billion with an increase of $370.41 \%$ compared to the year 2018.

Although it presents advances in international trade, the Brazilian government faces some challenges in the field of public policies for the insertion of its agricultural and livestock products in the international scenario that interfere with its competitiveness. According to Galetti (2010 as cited in Brandão \& Rodrigues da Conceição 2019, p. 130), Brazil presents an institutional organization that promotes dispersion of the mechanisms to support foreign trade in several agencies that mostly present a problem of overlapping of actions. In addition to these challenges, Arbache (2002 as cited in Brandão \& Rodrigues da Conceição, 2019, p. 123) also 
highlights those challenges linked to high costs in ports, the tax burden, labor costs, excessive bureaucracy, logistics problems, corruption, among others, which burden production and reduce international competitiveness.

The study that underpins the preparation of this article presents Benin as the first cotton exporting country in 2018 from Africa and the fifth world exporter and Brazil, the first exporter in Latin America and the second-largest cotton exporter in the world (United States Department of Agriculture, 2019).

Despite the importance of this sector in international trade, few scientific productions have been developed to give greater visibility to strengthen new guidelines, orientations, and adequate policies to improve the agricultural sector of Benin, in general, and the cotton complex in particular. Adopting these themes, the present study aims to analyze whether Benin and Brazil present Revealed Comparative Advantages for cotton exports (neither carded nor combed), and to analyze the Regional Orientation of this commodity for the main consumer markets.

The data used were collected from the International Trade Center (ITC)/ Trade Map and the United States Department of Agriculture (USDA).

This study becomes important in the process of methodological construction of analysis of the relationship between national and international economies from the examination of the peculiarity of export relations of agricultural products in Benin.

In this way, it is intended to offer a theoretical and methodological reference for research carried out in the field of economic sciences on foreign trade, even though it is presented as an explanation of the particularity of the exportation of a product from two specific nations.

\section{EVOLUTION OF COTTON PRODUCTION AND EXPORTS FROM BENIN AND BRAZIL FROM 2006 TO 2018}

\subsection{Brief history of cotton production in Benin}

Until the early 1990s, the supply of production inputs, the purchase of seed cotton, transport, ginning, and the export of fiber were all part of a parastatal society: the National Society for Agricultural Promotion (SONAPRA). This exclusivity was not always efficient. Thanks to the economic restructuring that took place in this decade, the Rural Development Policy Declaration Letter (LDPDR) was presented as a consequence of the liberalization of the sector. From that moment on, the country transferred some functions of the cotton sector to the private sector, as in the case of raw material production, processing, infrastructure maintenance, and production of knowledge and technology. Thereafter, several state and non-state actors have been active in the cotton sector since the beginning of the liberalization of the sector in 1991.

These different actors are grouped into three categories: direct actors, producer families (ginners and importers, input distributors); the structures of the Inter-professional Cotton Association and the Cotton Input Commission (central securitization of payments and recovery); and the structures of the State, Agricultural Research Center-Cotton Fiber (research production and applied technology).

This transfer of functions in this new organizational arrangement enabled the state to better perform the role of regulator. Twenty-six decrees/decisions were instituted between 1991 and 2012 for a reorganization of the cotton sector and also ensured the hierarchical supervision of the structures involved in the execution of the sector's critical functions.

\subsection{Benin's cotton production from 2006-2018}


After a record production of 108,900 tons in the $2007 / 2008$ cotton season (HS: 5201 ), the production of this product dropped dramatically to 65,300 tons in 2010/2011. This decrease in production is due to unfavorable weather conditions and the quality of insecticides used in production according to the Institut National de la Statistique et de l'Analyse Economique (2018). The $2011 / 2012$ crop showed a recovery in production going from 76,200 tons in $2012 / 2013$ to 119,700 tons.

In 2013/2014 the production level continued to rise this time to 125,200 tons and reaching 157,800 tons in $2014 / 2015$. In 2014 , cotton alone accounted for $44 \%$ of the total value of combined national exports (Institut National de la Statistique et de l'Analyse Economique, 2018).

Table 1: Cotton production in Benin 2006-2018

\begin{tabular}{|c|c|c|c|}
\hline Years & $\begin{array}{c}\text { Production (Mil. } \\
\text { Tons) }\end{array}$ & Areas (Mil. Ha) & $\begin{array}{l}\text { Productivity (ton / } \\
\text { ha) }\end{array}$ \\
\hline 2006 & 103.40 & 231.50 & 448.00 \\
\hline 2007 & 108.90 & 234.60 & 465.00 \\
\hline 2008 & 88.20 & 205.40 & 430.00 \\
\hline 2009 & 76.20 & 180.20 & 423.00 \\
\hline 2010 & 65.30 & 180.10 & 363.00 \\
\hline 2011 & 76.20 & 200.00 & 381.00 \\
\hline 2012 & 119.70 & 300.10 & 399.00 \\
\hline 2013 & 125.20 & 350.00 & 358.00 \\
\hline 2014 & 157.80 & 400.40 & 395.00 \\
\hline 2015 & 108.90 & 300.00 & 363.00 \\
\hline 2016 & 187.20 & 419.90 & 446.00 \\
\hline 2017 & 248.20 & 530.10 & 468.00 \\
\hline 2018 & 304.80 & 650.00 & 469.00 \\
\hline
\end{tabular}

${ }_{1}$ Productivity $(\mathrm{kg} / \mathrm{ha})=$ production / areas. Source: Author based on data from USDA and World Trade Organization (2019).

In the $2015 / 2016$ harvest, cotton production fell to 108,900 tons compared to the $2014 / 2015$ harvest. This drop has as main factors, the changes in climatic conditions (shortage of rain) in the northern region of the country. Other factors that stand out in most regions are the use of lower quality fertilizers in production and also the low price/kg paid to producers. Benin, with all the conditions in place, set a new record in cotton production going from 248,200 tons in 2017/2018 crop to 304,800 tons in the 2018/2019 crop according to Table 1.

Figure 1 shows slight growth in cotton productivity of $4.68 \%$ between 2006 and 2018. It is also possible to observe the decline in productivity between 2006 and 2015 that was 19\% and can be explained by the quality of inputs and the low price paid to producers (World Trade Organization, 2019). The upturn in productivity is due to the introduction of the production intensification program that promotes an increased dose of quality fertilizer and the combination of chemical and organic fertilizers according to the Inter-professional Cotton Association [AIC] (2016 as cited in Hougni \& Moreira, 2019, p.6). 


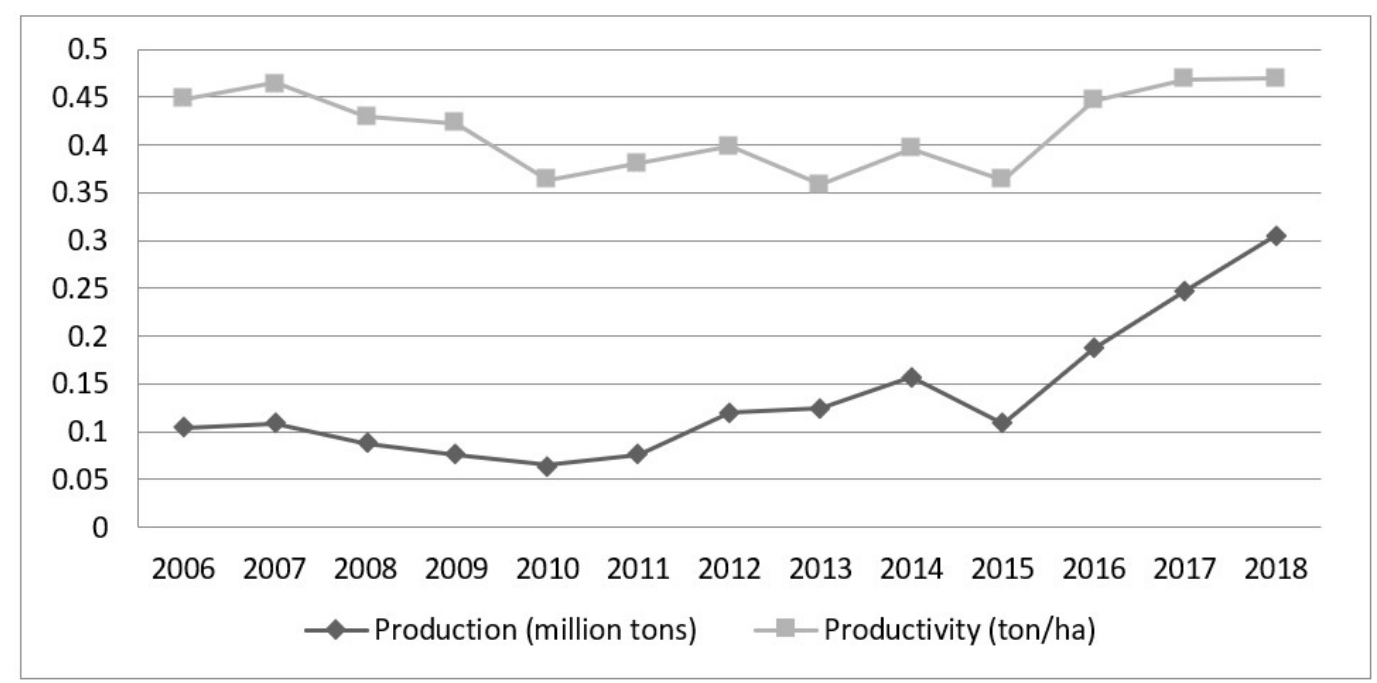

Figure 1: Evolution of cotton productivity and production in Benin between 2006 and 2018. Source: Author based on data from USDA and World Trade Organization (2019).

Thus, Benin became the first cotton producer in Africa in general and West Africa in particular according to USDA (2019). These latest production records in the period 2016 and 2018 were the first in the history of cotton in Benin and were made possible by the effective introduction of modern machinery in the agricultural sector, the payment of producers in real-time, and the availability of quality fertilizers for production (Institut National de la Statistique et de l'Analyse Economique, 2018).

Generally, cotton production is more concentrated in the northern part of the country, in the Alibori region, and, to a lesser extent, in the Borgou and Atacora regions.

\subsection{Brazil's cotton production from 2006-2018}

Brazil is the world's fourth-largest cotton producer in the 2018/2019 crop year and has earned second place in the ranking of the world's largest cotton exporters (United States Department of Agriculture, 2019).

Considering Table 2, we notice that the decrease in the world cotton production, in the analyzed period, was 3.35\%, going from 26.71 to 25.817 million tons. Brazil and Benin had, in this international scenario, an increase of $85.70 \%$ and $195.92 \%$ respectively with a positive correlation in the participation of the world production in the same period. Despite having a drop of $21.84 \%$ in its production in the period 2006 and 2018, China was the first in the ranking as the largest producer of cotton in 2018 followed by India and the United States. This leadership of India was due to the introduction of transgenic cotton in 2002, thus increasing productivity from 30 to 60\% (United States Department of Agriculture, 2019).

Table 2: Share of the world's largest cotton producers from 2006 to 2018

\begin{tabular}{ccccccc} 
& \multicolumn{2}{c}{2006} & & \multicolumn{2}{c}{2018} & Share \\
\cline { 2 - 3 } Country & $\begin{array}{c}\text { Production } \\
\text { (million } \\
\text { tons) }\end{array}$ & Share (\%) & & $\begin{array}{c}\text { Production } \\
\text { (million } \\
\text { tons) }\end{array}$ & Share (\%) & $\begin{array}{c}\text { Variation } \\
\text { (in p.p) }\end{array}$ \\
China & 7.729 & 28.94 & & 6.041 & 23.40 & -5.54 \\
\hline
\end{tabular}

Source: Author based on data from USDA and World Trade Organization (2019). Note: Ranking related to 2018. 
Table 2: Continued...

\begin{tabular}{|c|c|c|c|c|c|}
\hline \multirow[b]{2}{*}{ Country } & \multicolumn{2}{|c|}{2006} & \multicolumn{2}{|c|}{2018} & \multirow{2}{*}{$\begin{array}{c}\text { Share } \\
\text { Variation } \\
\text { (in p.p) }\end{array}$} \\
\hline & $\begin{array}{l}\text { Production } \\
\text { (million } \\
\text { tons) }\end{array}$ & Share (\%) & $\begin{array}{l}\text { Production } \\
\text { (million } \\
\text { tons) }\end{array}$ & Share (\%) & \\
\hline India & 4.833 & 18.09 & 5.617 & 21.76 & 3.67 \\
\hline United States & 4.700 & 17.60 & 3.998 & 15.49 & -2.11 \\
\hline Brazil & 1.524 & 5.71 & 2.830 & 10.96 & 5.25 \\
\hline Pakistan & 2.085 & 7.81 & 1.654 & 6.41 & -1.4 \\
\hline Turkey & 0.827 & 3.10 & 0.816 & 3.16 & 0.06 \\
\hline Uzbekistan & 1.165 & 4.36 & 0.730 & 2.83 & -1.53 \\
\hline Australia & 0.294 & 1.10 & 0.479 & 1.86 & 0.76 \\
\hline Greece & 0.337 & 1.26 & 0.306 & 1.19 & -0.07 \\
\hline Benin & 0.103 & 0.39 & 0.305 & 1.18 & 0.79 \\
\hline Turkmenistan & 0.305 & 1.14 & 0.198 & 0.77 & -0.37 \\
\hline Rest of world & 2.809 & 10.52 & 2.843 & 11.01 & 0.49 \\
\hline Total & 26.711 & 100.00 & 25.817 & 100.00 & - \\
\hline
\end{tabular}

Source: Author based on data from USDA and World Trade Organization (2019). Note: Ranking related to 2018.

Figure 2 shows the Brazilian cotton productivity growth of 23.99\% during 2006 and 2018.

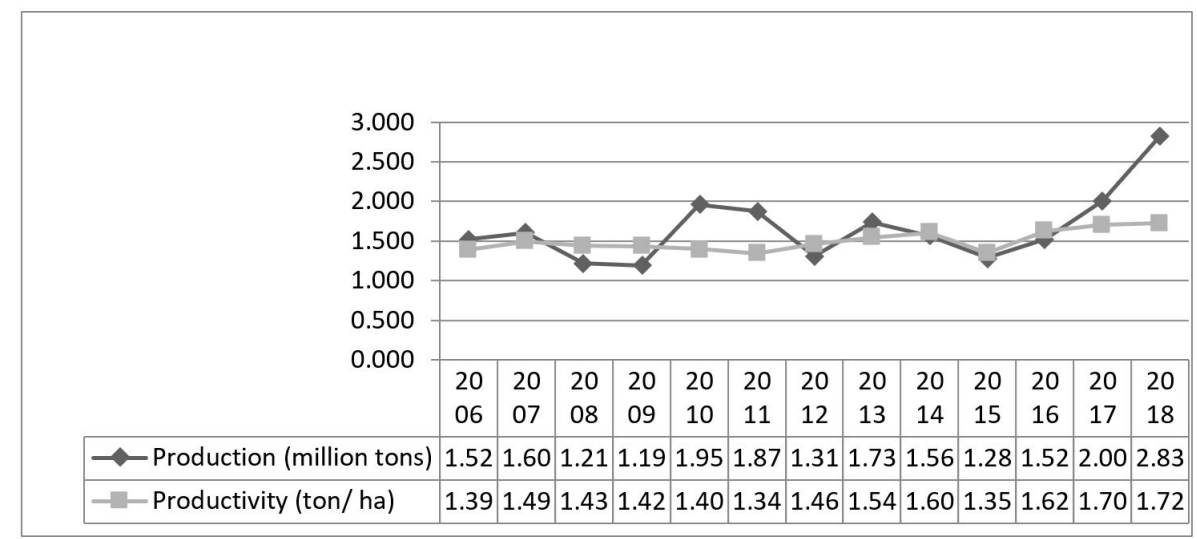

Figure 2: Evolution of cotton productivity and production in Brazil 2006-2018. Source: Author based on data from USDA and World Trade Organization (2019).

These gains in productivity observed from the 2015-2016 crop and until 2017-2018 in Brazil can be explained not only by genetic improvement and the application of appropriate techniques in the management of the Crop (Associação Brasileira dos Produtores de Algodão, 2016) but mainly by the strategies adopted for the improvement of the sector among the Federative Units (UFs). Indeed, according to Brandão \& Rodrigues da Conceição (2019), in addition to these gains in productivity and improved technology, the authors perceive a movement in the expansion of internal agricultural borders in the country. In the search for improvements in the sector, public policies and private initiatives took place from the junction of three ministries that hold propositional actions on this issue: the Ministry of Industry, Foreign Trade and Services (MDIC) and the Ministry of Agriculture, Livestock, and Supply (MAPA). Thus, four major objectives were defined for the increase of Brazilian exports: opening of international markets; expansion of exports to destination countries that have signed trade, sanitary and phytosanitary conventions; promotion of the Brazilian image of agricultural and livestock 
production in the international market and, finally, maintenance and resumption of markets (Brandão \& Rodrigues da Conceição, 2019).

Among the public policies, Portaria $n^{\circ} 1.066$, published on August 6, 2018, which provides a general strategy for Brazil's participation in the international market, stands out. According to Brasil (2018 as cited in Brandão \& Rodrigues da Conceição, 2019), this strategy involves tariff issues, related to taxes and quotas, and non-tariff issues, related to intellectual property, technical regulations, sustainability, climate change, and biotechnology, sanitary and phytosanitary issues, and others.

On the other hand, it is possible to observe a drop in the productivity in the 2014/2015 harvest, due to the reduced crop, resulting from unfavorable weather conditions (Brasil, 2019).

\subsection{Benin-Brazil cotton exports from 2006-2018}

Benin's cotton exports have increased by 513\% between 2006 and 2018 which points to the sector's performance in the country's GDP. In 2015 and 2016, there were declines in cotton exports specifically due to poor weather conditions. Drought during the sowing period in 2015, led to a significant decline in cotton production during the following 2016 crop (International Trade Center, 2015), as shown in Figure 3 below:

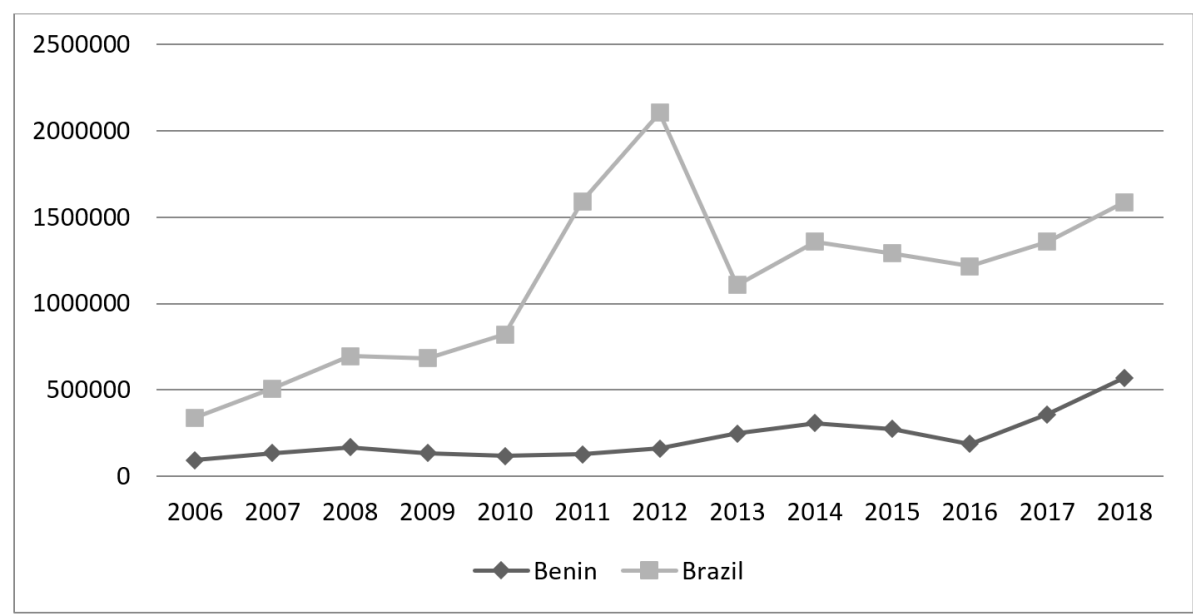

Figure 3: Benin-Brazil cotton exports from 2006-2018 (in US\$ Thousand). Source: Author based on data from USDA and World Trade Organization (2019).

In the same graph, one can see that Brazil's exports had a significant increase of $522.5 \%$ between 2006 and 2012 of the period under analysis. This increase in this period was possible mainly in the 2011/2012 harvest because the U.S, the world's leading exporter, suffered a shortfall due to a major drought and only produced $9 \%$ less than the previous harvest and consequently exported less.

In the 2011/2012 crop, Brazil broke the export record and achieved the third position in the world ranking with a volume of 1.043 million tons exported (Associação Brasileira dos Produtores de Algodão, 2012). However, in the following harvest, i.e. 2012/2013, there was a significant drop in Brazilian cotton exports. This decrease in exports can be explained by the reduction in cotton prices combined with the sharp increase in soybean prices.

This reduction is reflected in production and consequently in cotton exports in that crop. The fall in the 2014/2015 and 2015/2016 harvests is due to the smaller area planted in the 
North and Northeast regions, where the crops were damaged by poor rainfall distribution in the cotton-producing states, especially in Bahia, Maranhão, Piauí, and Tocantins. With this, there was a retraction in production, closing the 2015/2016 crop in 1.29 million tons against 1.563 million tons of the previous crop, which was already below the 2013/2014 crop, with 1.734 million tons of lint (Associação Brasileira dos Produtores de Algodão, 2016).

Table 3 below shows cotton exports by countries in Africa in general and in West Africa in particular in 2018. Cotton exports in 2018 led Benin to be the first largest exporter of the product in West Africa with $35.42 \%$ of cotton exports in that economic block (International Trade Center, 2015).

Table 3: Share of Benin's cotton exports in Africa in 2018

\begin{tabular}{|c|c|c|c|c|c|}
\hline \multirow[b]{2}{*}{ Countries } & \multicolumn{2}{|c|}{2018} & \multirow[b]{2}{*}{ Countries } & \multicolumn{2}{|c|}{2018} \\
\hline & $\begin{array}{l}\text { Exports } \\
\text { (ton) }\end{array}$ & $\begin{array}{c}\text { Share (\%) } \\
\text { África }\end{array}$ & & Exports (ton) & $\begin{array}{c}\text { Share (\%) } \\
\text { West of } \\
\text { Africa }\end{array}$ \\
\hline Benin & 259,577 & 25.13 & Benin & 259,577 & 35.42 \\
\hline Burkina & 197,687 & 19.14 & Burkina & 197,687 & 26.97 \\
\hline Ivory-Coast & 165,433 & 16.01 & Ivory-Coast & 165,433 & 22.57 \\
\hline Sudan & 91,299 & 8.84 & Mali & 50,161 & 6.84 \\
\hline Mali & 50,161 & 4.86 & Togo & 48,493 & 6.62 \\
\hline Togo & 48,493 & 4.69 & Senegal & 6,863 & 0.94 \\
\hline Egypt & 43,511 & 4.21 & Nigeria & 2,140 & 0.29 \\
\hline Zimbabwe & 42,310 & 4.10 & Guinea & 1,390 & 0.19 \\
\hline Zambia & 28,971 & 2.80 & Ghana & 1,202 & 0.16 \\
\hline Tanzania & 28,406 & 2.72 & Rest of the world & 0,000 & 0.00 \\
\hline Rest of the world & 77,187 & 7.47 & Total & 732.946 & 100.00 \\
\hline Total & $1,033,035$ & 100.00 & & & \\
\hline
\end{tabular}

Source: Author based on data from USDA and World Trade Organization (2019).

This performance by Benin made it the first largest exporter in Africa in the same year with a $25.13 \%$ share of total combined cotton exports in that large economic block (United States Department of Agriculture, 2019). In addition, direct competitors in Africa are Burkina (19.14), Ivory Coast (16.01\%), Sudan (8.84\%), Mali (4.86\%), and Togo (4.69\%). The top three countries (Benin, Burkina, and Ivory Coast) account for more than $60 \%$ of the continent's total cotton exports in 2018.

Table 4 shows the participation of the world's leading cotton exporters in the analyzed period. We observed that in 2018, the top five cotton exporters were the United States, India, Australia, Brazil, and Benin.

Table 4: Share of the world's largest cotton exporters 2006 and 2018

\begin{tabular}{|c|c|c|c|c|c|}
\hline \multirow[b]{2}{*}{ Countries } & \multicolumn{2}{|c|}{2006} & \multicolumn{2}{|c|}{2018} & \multirow{2}{*}{$\begin{array}{c}\text { Share } \\
\text { variation } \\
\text { (in p.p) }\end{array}$} \\
\hline & $\begin{array}{c}\text { Exports } \\
\text { (million } \\
\text { tons) }\end{array}$ & Share (\%) & $\begin{array}{c}\text { Exports } \\
\text { (million tons) }\end{array}$ & Share $(\%)$ & \\
\hline United States & 3.508 & 40,3 & 3.575 & 40.0 & -0.3 \\
\hline Brazil & 0.304 & 3.49 & 0.915 & 10.15 & 6.7 \\
\hline Australia & 0.583 & 6.70 & 0.899 & 9.97 & 3.3 \\
\hline
\end{tabular}

Source: Author based on data from USDA and World Trade Organization (2019). (-) means value not informed. Note: Ranking related to 2018. 
Table 4: Continued...

\begin{tabular}{|c|c|c|c|c|c|}
\hline \multirow[b]{2}{*}{ Countries } & \multicolumn{2}{|c|}{2006} & \multicolumn{2}{|c|}{2018} & \multirow{2}{*}{$\begin{array}{c}\text { Share } \\
\text { variation } \\
\text { (in p.p) }\end{array}$} \\
\hline & $\begin{array}{c}\text { Exports } \\
\text { (million } \\
\text { tons) }\end{array}$ & Share $(\%)$ & $\begin{array}{c}\text { Exports } \\
\text { (million tons) }\end{array}$ & Share (\%) & \\
\hline India & 0.860 & 9.87 & 0.767 & 8.51 & -1.4 \\
\hline Benin & 0.076 & 0.87 & 0.259 & 2.87 & 2.0 \\
\hline Greece & 0.333 & 3.82 & 0.215 & 2.38 & -1.44 \\
\hline Burkina Faso & - & - & 0.198 & 2.20 & - \\
\hline Ivory-Coast & 0.096 & 1.10 & 0.165 & 1.83 & 0.73 \\
\hline Uzbekistan & - & - & 0.116 & 1.29 & - \\
\hline Argentina & 0.002 & 0.023 & 0.101 & 1.12 & 1.10 \\
\hline Rest of the world & 2.944 & 33.82 & 1.81 & 20.03 & -13.79 \\
\hline Total & 8.706 & 100.00 & 9.016 & 100.00 & - \\
\hline
\end{tabular}

Source: Author based on data from USDA and World Trade Organization (2019). (-) means value not informed. Note: Ranking related to 2018.

Brazil was the world's second-largest exporter of cotton in 2018 when the country exported 0.915 million tons of the product while Benin ranked fifth (United States Department of Agriculture, 2019). In the same period, Brazil accounted for 10.15 percent of world exports while Benin accounted for 2.87 percent of cotton exports (United States Department of Agriculture, 2019).

In the sequence, Australia exported 899,529 tons, the United States exported 3,574,865 tons and Benin 259,577 tons. These top five countries account for approximately $72 \%$ of the world's cotton exports.

World cotton exports are mostly topped by the United States, which in 2018/2019 crop reached $40.0 \%$ in total combined exports, followed by Brazil, Australia, India, and Benin with $10.15 \%, 9.97 \%, 8.51 \%$, and $2.87 \%$ respectively. At this international juncture, Brazil stood out as the second-best cotton exporter with a change in share of +6.7 between 2006 and 2018. This innovative result was possible due to the good profitability of the crop and has guaranteed the interest of farmers. Even with the high cost of production due to the high technology employed in cultivation, cotton presents a return of about $38.7 \%$ on the investment in planting the lint, according to the National Supply Company [Conab] (2019).

Regarding the other competitors in the international cotton trade, we noticed that countries such as Australia (4.4\%), Brazil (6.9\%), Benin (2.0\%), Ivory Coast (0.8\%), and Turkey (0.3\%) had a growth in exports in 2006 and 2018 while in Greece (1.2\%) and United States (0.2\%) we observed a reduction in the same period.

\section{METHODOLOGICAL ASPECTS}

\subsection{Methodology}

The methodology used in this study for a probable existence of Benin-Brazil product competitiveness is based on the calculation of revealed comparative advantages and regional orientation indices.

\subsubsection{Revealed Comparative Advantage Index (RCAI)}

Balassa (1965) developed the comparative advantage index to assess the share of a country's exports of a product relative to its world exports, relative to the share of the country's total 
exports relative to total world exports. In general, the RCAI or RCA index can be expressed as follows:

$$
\operatorname{RCAI}_{\mathrm{ij}}=\frac{X_{i j} / X_{i z}}{X_{j} / X_{z}}
$$

on what $X_{i j}$ represents the value of exports of product i from object economy $j ; X_{i z}$ represents the value of exports of product i from reference economy $z_{;} X_{j}$ is the value of total exports from object country $j$ and $X_{z^{\prime}}$ the total value of exports from reference country $z$.

This index consists of a ratio of proportions in which the result corresponds to the division of the share of exports of product i in the total exports of country $j$, by the participation of exports of the same product in the total exports of country $z$. When the RCAI $>1$, product $i$ has revealed comparative advantage, if the $\mathrm{RCAI}<1$, then product $\mathrm{i}$ has revealed comparative disadvantage. It happens rarely that the RCAl equals 1 (one) notifying that product i has neither comparative advantage nor comparative disadvantage.

\subsubsection{Symmetric Revealed Comparative Advantage Index (SRCAI)}

One of the limitations of the Index of comparative advantage proposed by Balassa (1965) lies in its asymmetric dimension of comparative advantage and disadvantage. According to Hidalgo (2005), comparative advantage varies between 0 and 1, and disadvantage between 1 and infinity. To overcome this problem, Laursen (1998) developed a normalization index as follows:

$S R C A I_{i j}=\frac{\left(R C A_{i j}-1\right)}{\left(R C A_{i j}+1\right)}$

The RCA index varies between -1 and 1 and if the value of the SRCA ${ }_{i j}$ index is between 0 and 1 , we say that country $j$ has revealed comparative advantage in the product $i$. If the value of the SRCA index is in the range -1 to 0 they indicate that this country has no revealed comparative advantage in the product $\mathrm{i}$.

\subsubsection{Cotton's Contribution to Trade Balance Index (CTBI) 2006-2018}

The Contribution to Trade Balance Index (CTBI), defined by Lafay (1990) is also an index of revealed comparative advantage. This revealed comparative advantage indicator was created to overcome some of the limitations in the calculation of the Balassa (1965) index. Lafay's (1990) indicator takes into account the imports missing in the expression of Balassa's (1965) index and also takes into account exports to make a comparison of the CTBI. This indicator is given as follows:

$C T B I_{i j}=\frac{100}{(X+M) / 2}\left[\left(X_{i}-M_{i}\right)-(X-M) \frac{\left(X_{i}+M_{i}\right)}{(X+M)}\right]$,

where $X_{i}$ refers to exports of good $i$ and $M_{i}$ refers to imports of the same good and $X$ and $M$, respectively, the total exports and imports of that region. The first term in brackets in the expression $\left(\mathrm{X}_{\mathrm{i}}-\mathrm{M}_{\mathrm{i}}\right)$ represents the observed trade balance of product $\mathrm{i}$ and the second term in brackets represents the theoretical trade balance of product $\mathrm{i}$. 


$$
(X-M) \frac{\left(X_{i}+M_{i}\right)}{(X+M)}
$$

If $\mathrm{CTBI}_{\mathrm{ij}}>0$ then product i has revealed comparative advantage and if $\left.\mathrm{CTBI}\right|_{i j}<0$ then product $i$ has revealed comparative disadvantage.

From the calculations that will be made based on the data obtained from exports and imports of products in the country, the products with revealed comparative advantages will be presented, achieving the objectives of this work already defined above.

\subsubsection{Regional Orientation Index (ROI)}

In this study, this index analyzes the orientation of cotton exports from Benin and Brazil. The result of the ROI comes from the division of exports between two ratios: the share of exports of the country's product to a particular region in the total exports of the country to the rest of the world in the total exports of the country.

The regional orientation index for product $\mathrm{j}$ is defined as follows:

$$
\mathrm{ROI}=\frac{X_{i j} / X_{i}}{X_{r j} / X_{r}},
$$

on what $X_{i j}$ is the value of exports from product country $j$ to object region $i ; X_{i}$ represents the total exports from this country to object region $i ; x_{r j}$ is the value of exports from product country $j$ to the rest of the world; $X_{r}$ corresponds to the value of total exports from the country to the rest of the world. According to Yeats (1997), the ROI assumes values between zero and infinity. When $\mathrm{ROI}=1$, there is no defined trend for any particular region, that is, there is the same propensity to export for any of the regions under analysis.

\subsection{Analysis Standards}

To verify the regional orientation of cotton exports (neither carded nor combed) from Benin and Brazil, the following consumer markets for each commodity were analyzed respectively:

a. Destination market for cotton from Benin: Asia, EU-28;

b. Brazil's cotton destination market: Asia, EU-28.

\section{ANALYSIS AND DISCUSSION OF THE RESULTS}

In this section, we discussed the results obtained from the competitiveness and regional orientation indicators for Benin and Brazil respectively.

\subsection{Revealed Comparative Advantage and Symmetric Revealed Comparative Advantage Indices of cotton 2006-2018}

According to Table 5, the values found are greater than the unit for the RCAI and close to the unit for the SRCAI throughout the analyzed period, which indicates that Beninese and Brazilian cotton (neither carded nor combed) are dynamic sectors with great importance in the world export agenda. 
Table 5: Revealed and Symmetric Comparative Advantage Index of cotton 2006-2018

\begin{tabular}{llllllllllllll} 
Years & 2006 & $\mathbf{2 0 0 7}$ & $\mathbf{2 0 0 8}$ & $\mathbf{2 0 0 9}$ & $\mathbf{2 0 1 0}$ & $\mathbf{2 0 1 1}$ & $\mathbf{2 0 1 2}$ & $\mathbf{2 0 1 3}$ & $\mathbf{2 0 1 4}$ & $\mathbf{2 0 1 5}$ & $\mathbf{2 0 1 6}$ & $\mathbf{2 0 1 7}$ & $\mathbf{2 0 1 8}$ \\
$\begin{array}{l}\text { Benin } \\
\text { RCAI }\end{array}$ & 461.1 & 591.0 & 543.3 & 454.1 & 220.8 & 278.3 & 315.6 & 406.6 & 396.9 & 625.1 & 682.8 & 676 & 325 \\
SRCAI & 0.996 & 0.997 & 0.996 & 0.996 & 0.991 & 0.993 & 0.994 & 0.995 & 0.995 & 0.997 & 0.997 & 0.99 & 0.99 \\
Brazil & & & & & & & & & & & & & \\
RCAI & 2.69 & 3.81 & 4.79 & 6.38 & 4.04 & 5.31 & 7.79 & 4.47 & 7.50 & 9.59 & 9.76 & 8.02 & 8.57 \\
SRCAI & 0.46 & 0.59 & 0.66 & 0.73 & 0.60 & 0.68 & 0.77 & 0.63 & 0.76 & 0.81 & 0.82 & 0.79 & 0.80 \\
\hline
\end{tabular}

Source: Author based on data from USDA and World Trade Organization (2019).

Benin's cotton RCAl shows the best results, indicating the comparative advantages in the production of this commodity when compared to that of Brazil. In 2016, the index reached 682.8 for Benin, a growth of approximately $48 \%$ compared to 2006 and a decrease of $30 \%$ between 2006 and 2018.

In the same period in 2016, Brazil's RCAI reached its maximum value of 9.76 with a growth of $262.82 \%$ compared to 2006 and next to a decrease of $12.19 \%$ compared to 2018 . We observed a retreat of the competitiveness index when we go from one year to another, and this is mainly due to the slow international economic environment and the effects of the international economic and financial crises that hit the world between 2008 and 2009.

It is worth noting that the index of symmetrical revealed comparative advantage (SRCAl) of Brazil presented on average 0.7 values close to unity and the best value of the index is in 2016 with 0.82 in the period analyzed. Refers to Benin, this index presented on average 0.99 very close to unity, and also its best value is in 2016 with 0.997 in the period analyzed.

Benin's results corroborate with those found by Owoundi (2013). According to the author, within the West African Economic and Monetary Union [UEMOA] block (2014), Benin, with its agricultural policy, managed to stand out from the others as the first exporting country with the highest degree of competitiveness. This was possible taking into account the opening of trade that facilitated free trade through the removal of tariff and non-tariff barriers with some of its trading partners.

Similarly, the results found for Brazil confirm with those of the work of Copetti \& Coronel (2019a) on competitiveness using the SRCAI for Brazil and Australia. For the author, Brazil showed symmetric revealed comparative advantage between 2000 and 2017, but Australia is more competitive than Brazil in the same period because it has a higher SRCAI average than Brazil, that is, 0.775 for Australia and 0.578 for Brazil in the same period. The results of the recent study by Copetti \& Coronel (2019b) on the analysis of the competitiveness of Brazilian cotton exports corroborate those found in the present article. For the authors, both Brazil and the United States had revealed comparative advantages for cotton between 2001 and 2017. Also according to Ferreira Filho et al. (2009), their results point out that, "In Brazil, there is greater competitiveness, with high productivity, but costs considered high per hectare and also the risk of the crop is high, due to narrow margins and sunk costs."

\subsection{Contribution Index to the Trade Balance of cotton (CITB)}

According to Table 6, the cotton product, which has a revealed comparative advantage, contributes significantly to the trade balance. Thus, it can be said that Benin and Brazil jointly have revealed comparative advantages in the production and export of cotton during the period of analysis. 
Table 6: Contribution Index to the Trade Balance of cotton from 2006 to 2018

\begin{tabular}{ccccccccccccccc} 
Year & 2006 & 2007 & 2008 & 2009 & 2010 & 2011 & 2012 & 2013 & 2014 & 2015 & 2016 & 2017 & 2018 \\
CITB & 24.83 & 24.1 & 25.24 & 21.52 & 14.25 & $\begin{array}{c}17.25 \\
\text { Benin } \\
\text { Brazil }\end{array}$ \\
CITB & 0.13 & 0.21 & 0.32 & 0.43 & 0.37 & 0.45 & 0.86 & 0.44 & 0.58 & 0.67 & 0.61 & 0.56 & 0.63 \\
\hline
\end{tabular}

Source: Author based on data from USDA and World Trade Organization (2019).

Importantly, Benin's cotton has been increasing its share to the country's trade balance and went from 24.83 in 2006 to 30.48 in 2017, that is, an increase of $22.77 \%$ between these two periods, but the index remains fluctuating from one year to another.

Cotton from Brazil poorly contributes to the country's trade balance but continues to be greater than zero. This index presented in 2012 its highest participation in the country's trade balance. Thus, Brazil has a revealed comparative advantage in cotton exports.

However, the RCAI and SRCAI do not indicate to which countries or blocks are directing the cotton exports, being necessary the analysis of the Regional Orientation Index (ROI).

\subsection{Regional Orientation Indices of cotton for Asia}

The Regional Orientation Index (ROI) identifies whether the exports of a country are oriented to a particular country or economic block. According to Table 7, the calculated values of the $\mathrm{ROI}$ for Asia were greater than the unit throughout the analyzed period, thus indicating that the Beninese and Brazilian cotton exports are oriented towards this economic block.

One of the factors that explain the trend of Beninese cotton exports to Asia are the long-term contracts made by Asian firms and also the flexibility in the agreements, favoring a greater penetration of this product in this economic block (International Trade Center, 2015).

Table 7: Regional Orientation Index of cotton for Asia 2006-2018

\begin{tabular}{ccccccccccccccc} 
Year & 2006 & 2007 & 2008 & 2009 & $\mathbf{2 0 1 0}$ & $\mathbf{2 0 1 1}$ & $\mathbf{2 0 1 2}$ & $\mathbf{2 0 1 3}$ & $\mathbf{2 0 1 4}$ & $\mathbf{2 0 1 5}$ & $\mathbf{2 0 1 6}$ & $\mathbf{2 0 1 7}$ & $\mathbf{2 0 1 8}$ \\
ROI & 6.50 & 5.74 & 12.88 & 17.20 & 30.75 & $\begin{array}{c}12.21 \\
\text { Benin } \\
\text { Brazil }\end{array}$ \\
ROI & 15.64 & 24.74 & 19.18 & 17.73 & 29.76 & 26.29 & 47.33 & 50.65 & 55.48 & 55.65 & 47.98 & 50.91 & 58.94 \\
\hline
\end{tabular}

Source: Author based on data from USDA and World Trade Organization (2019).

However, despite the ROI is higher than the unit, it has been fluctuating in some periods under analysis, although the Beninese cotton exports to Asia have been increasing. This is due to the little diversification of Beninese cotton exports to new markets beyond the analyzed block.

Benin's ROI analysis indicates a 245\% increase from 6.5 in 2006 to 22.48 in 2018. Between 2011 and 2016, the index showed declines, which may be related to the drop in the cotton production. The biggest drop between 2014 and 2016 is explained not only by bad weather conditions but also by successive government decrees that weakened farmer organizations that lost all their capacities to defend the interests of their members.

Regarding Brazil's ROI throughout the analyzed period, from 2006 to 2018, cotton exports were oriented to Asia, and the ROI presented, throughout the analyzed period, quite high values, indicating a strong orientation of exports of this commodity to that market. According to International Trade Center (2015), Brazil exported 97.9\% of its cotton lint exports to Asia. This increase in Brazilian cotton sales to Asia resulted from the trade war between China the United States. In the work of Copetti \& Coronel (2019b), Brazil's ROI to Turkey was increasing 
from 4.07 in 2005 to 19.0 in 2017 and an increase in exports of 2,100\% (US $\$ 8.52$ million in 2005 and US $\$ 187.43$ million in 2017).

Similarly, Brazilian cotton to Vietnam accounted for $19.79 \%$ of the combined Brazilian exports between 2000-2017 with an increase of $24,466 \%$ of Brazilian exports to Vietnam in the same period (US \$ 7.05 million in 2005 and \$ 1.73 billion in 2017) and finally, Brazilian cotton lint exports to Indonesia had a growth of $13,467 \%$ in the analyzed period. According to Copetti \& Coronel (2019b), the ROI indicated that Brazil's cotton exports are directed toward Indonesia, Vietnam, and Turkey from 2001 to 2017.

Both Brazil and Benin have their cotton sales mostly directed to the economic block (Asia), a potential consumer of this commodity.

\subsection{Regional Orientation Index of Cotton for EU-28}

Table 8 below presents the ROI results for the EU-28. The data point to values very close to zero for both countries under analysis, indicating that extra-EU-28 cotton exports weigh more heavily in the national export mix than intra-EU-28 exports.

Table 8: Regional Orientation Index of cotton for EU-28 2006-2018

\begin{tabular}{cccccccccccccc} 
Year & $\mathbf{2 0 0 6}$ & $\mathbf{2 0 0 7}$ & $\mathbf{2 0 0 8}$ & $\mathbf{2 0 0 9}$ & $\mathbf{2 0 1 0}$ & $\mathbf{2 0 1 1}$ & $\mathbf{2 0 1 2}$ & $\mathbf{2 0 1 3}$ & $\mathbf{2 0 1 4}$ & $\mathbf{2 0 1 5}$ & $\mathbf{2 0 1 6}$ & $\mathbf{2 0 1 7}$ & $\mathbf{2 0 1 8}$ \\
Benin & 0.67 & 0.77 & 0.55 & 0.64 & 0.98 & 0.87 & 0.31 & 0.36 & 0.46 & 0.57 & 0.38 & 0.12 & 0.10 \\
Brazil & 0.15 & 0.05 & 0.07 & 0.05 & 0.03 & 0.06 & 0.05 & 0.06 & 0.05 & 0.05 & 0.06 & 0.09 & 0.06 \\
\hline
\end{tabular}

Source: Author based on data from USDA and World Trade Organization (2019).

Table 8 shows that the ROI of cotton from Benin has values close to zero, especially in recent years, demonstrating the low entry of the Beninese product in the EU-28. The highest value of the index is verified in 2010 but is below the unit. Cotton exports from Benin to the EU-28 were of the order of US $\$ 12.23$ million, the highest value exported by the country in the analyzed period. The weak penetration of the Beninese product in the EU-28 is explained, in part, by the requirements in tariff and non-tariff restrictions imposed by the EU-28 (specifically France and Belgium) (International Trade Center, 2015).

Quality, hygiene, and production process requirements apply only to exported agricultural and food products. About $80 \%$ of the non-tariff measures in this category are mandatory and are very strict. These requirements concern in particular the quality, ripeness, sizing, or sugar content of certain fruits. More investment is needed by Benin to qualify and gain access to this high-income market with much potential demand (International Trade Center, 2015).

In the same vein, Brazil's ROI results for the EU-28 also point to values very close to zero, indicating that Brazil's extra-EU-28 cotton exports weigh more heavily in the national export mix than intra-EU-28 exports. Brazil has not yet tapped into a high-income market with much potential demand, because of tariff and non-tariff restrictions imposed by the EU-28 as barriers to protect its economy.

According to the Ministry of Development, Industry and Foreign Trade [MDIC] (2020), the main commodities exported in 2018 to the European Union were soybean meal, iron ore, pulp, coffee beans, crude oil, soybeans, copper ore, among others.

\section{CONCLUSIONS}

This paper analyzes the competitiveness of Beninese cotton exports (neither carded nor combed) between 2006 and 2018 about Brazil, the second-largest cotton producer in international 
trade. In this context, we analyzed the participation rate in world production and exports, the indexes of revealed and symmetrical comparative advantage, the contribution to the trade balance index, and finally the index of regional orientation for respective countries.

Regarding the participation rate in world cotton production, the results show a variation in participation of $+5.25 \%$ in world production for Brazil, going from $5.71 \%$ of total world production in 2006 to $10.96 \%$ in 2018. Regarding Benin, this variation was +0.79 going from $0.39 \%$ in 2006 to $1.18 \%$ in 2018 . For exports, regarding the participation rate in world cotton exports, the results point to a variation in participation of $+2 \%$ in world exports for Benin going from $0.87 \%$ of total world production in 2006 to $2.87 \%$ in 2018 while for Brazil, this variation was much better (+6.7) going from $3.49 \%$ in 2006 to $10.15 \%$ in 2018 . Considering the productivity issue, Brazil is more productive with an average of $1.498 \mathrm{ton} / \mathrm{ha}$ in the analyzed period while Benin was less productive with an average of 0.416 ton/ha compared to Brazil in the same period.

Concerning competitiveness, the analysis of the SRCAl indicated that Benin and Brazil have been showing revealed comparative advantages for cotton throughout the study period. In addition, Benin was more competitive than Brazil by having a higher average ( 0.99 and 0.7 respectively). This result can be explained in technological terms. According to Fagerberg \& Srholec (2004), less advanced countries have a higher capacity to adapt to new technologies than developed countries.

About the regional orientation index (ROI), the results obtained indicate that cotton exports from Brazil and Benin are strongly oriented towards Asia, the main consumer of this product, and weakly oriented towards the EU-28. One of the major obstacles that cotton exports face concerns the tariff and non-tariff barriers that major markets impose. Thus, Benin and Brazil need to broaden negotiations to diversify this product in the international market through indications of possibilities related to the implementation of trade policies, to redirect cotton to markets that present greater dynamism in their imports with higher per capita income as the United States, the EU-28 block, and NAFTA.

This article can become a reference for decisions about investments (public or private) in the right products at the opportune moments of reformatting the agricultural policy guidelines of countries with political and economic profiles similar to that of Brazil and Benin.

One of the limitations of this work is related to the calculated indices that do not take into consideration the different market oscillations of the product, such as the variation in the price of cotton and the geographical proximity. Although the research has not been dedicated to the analysis of storage, logistics, and disposal of the production, these stages and conditions result in high costs for disposal and interfere in the competitiveness of the countries analyzed.

\section{REFERENCES}

Arbache, J. S. (2002). Comércio internacional, competitividade e políticas públicas no Brasil (Texto para Discussão, no. 903). Brasília: Ipea.

Associação Brasileira dos Produtores de Algodão - ABRAPA. (2012). Relatório de gestão 2011 2012. Retrieved in February 15, from https://www.abrapa.com.br/Bibliotecalnstitucional/ relatorio_gestao.pdf

Associação Brasileira dos Produtores de Algodão - ABRAPA. (2016). Relatório gestão 2015-2016. Retrieved in 2020, March 28, from https://www.abrapa.com.br/Documents/relatorio_ gestao_2015_2016_preview.pdf 
Associação Brasileira dos Produtores de Algodão - ABRAPA. (2020). Algodão no mundo. Retrieved in 2020, March 28, from https://www.abrapa.com.br/Paginas/Dados/Algod\%C3\%A30\%20 no\%20Mundo.aspx

Balassa, B. (1965). Trade liberalization and revealed comparative advantage. Washington, DC: Word Bank.

Brandão, J. B., \& Rodrigues da Conceição, J. C. P. (2019). Desafios da inserção competitiva internacional. In J. E. R. Vieira Filho (Org.), Diagnóstico e desafios da agricultura brasileira (Cap. 4). Rio de Janeiro: IPEA.

Brasil. Casa Civil da Presidência da República. (2018). Portaria n 1.066, de 6 de agosto de 2018. Documento base para estratégia. Diário Oficial [da] República Federativa do Brasil, Brasília.

Brasil. Companhia Nacional de Abastecimento - CONAB. (2019). Brasil deve bater recorde de exportações de algodão em 2019. Retrieved in 2020, March 28, from https://www.conab. gov.br/ultimas-noticias/2967-brasil-deve-bater-recorde-de-exportacoes-de-algodao-em 2019\#: :text=A\%20expectativa\%20da\%20Companhia\%20Nacional,t\%2C\%20entre\%20 pluma\%20e\%20caro\%C3\%A7o

Copetti, L. S., \& Coronel, D. A. (2019a). Competitividade das exportações brasileiras e australianas de algodão: uma análise por meio de indicadores de comércio internacional. Revista Observatorio de la Economía Latinoamericana. Retrieved in 2020, March 28, from https:// www.eumed.net/rev/oel/2019/02/exportacoes-brasileiras-australianas.html

Copetti, L. S., \& Coronel, D. A. (2019b). Análise da competitividade das exportações brasileiras de algodão. Revista ADM, 19(23), 70-87.

Fagerberg, J., \& Srholec, M. (2004). Structural changes in international trade: cause, impact and response. Revue Économique, 55, 1071-1097.

Ferreira Filho, J. B., Alves, L. R. A., \& del Villar, P. M. (2009). Estudo da competitividade da produção de algodão entre Brasil e Estados Unidos - safra 2003/04. Revista de Economia e Sociologia Rural, 47(1), 59-88.

Galetti, J. R (2010). As políticas públicas de financiamento à exportação no Brasil (BNDES, Exime PROEX): características e efeitos sobre as exportações das empresas industriais brasileiras (Dissertação de mestrado). Instituto de Economia, Universidade Estadual de Campinas.

Hidalgo, Á. B. (2005). Inserção das regiões brasileiras no comércio internacional: os casos da Região Nordeste e do Estado de Pernambuco. Ensaios FEE, (2), 965-1018.

Hougni, A., \& Moreira, A. (2019). L'aide au développement du coton avant et après 2003 et I'initiative C-4: le cas du Bénin. Retrieved in 2020, March 28, from https://www.wto.org/english/ tratop_e/agric_e/item_8_c_article_hougni_et_moreira_cottondevassistance_wto2019_fr.pdf

Institut National de la Statistique et de l'Analyse Economique - INSAE. (2018). Un coup d'oeil sur les données du Benin. Retrieved in 2020, March 28, from http://www.insae-bj.org/

International Trade Center - ITC. (2015). Bénin: perspectives des entreprises: série de I'ITC sur les mesures non tarifaires (No. TMI-2017-88.F, pp. 24-25). Geneve: ITC.

International Trade Center - ITC. (2020). Trade Map, statistics for international business development. Retrieved in 2020, March 20, from https://www.trademap.org/Index.aspx

Lafay, G. (1990). La Mesure des avantages comparatifs revelés. Economie Prospective Internationale, 1(41), 27-43. 
Laursen, K. (1998). Revealed comparative advantage and the alternatives as measures of international specialization (Working Paper, No. 98-30). Copenhagen: Danish Research Unit for Industrial Dynamics.

Owoundi, J. P. (2013). Compétitivité et Intégration Commerciale des pays de la CEMAC: avantages comparatifs et contribution au solde commercial. Retrieved in 2020, March 28, from https:// competitivite.ferdi.fr/pays/benin

United States Department of Agriculture - USDA. (2019). Foreign agricultural service. Retrieved in 2020, March 28, from https://ipad.fas.usda.gov/cropexplorer/cropview/commodityView. aspx?cropid $=2631000 \&$ sel_year $=2018$

Vieira Filho, J.E.R. \& Fishlow, A. (2017). Agricultura e indústria no Brasil: inovação e competitividade. Brasília: Ipea.

World Trade Organization - WTO. (2019). World Trade statistical review. Retrieved in 2020, March 28, from https://www.wto.org/english/res_e/statis_e/wts2019_e/wts2019_e.pdf

Yeats, A. (1997, february). Does Mercosuls trade performance raise concerns about the effects of regional trade arrangements? (Policy, Planning and Research Working Paper, No. 1729). Washington: Bank Mundial. 